\title{
'Keeping Up the Good Fight': the said and unsaid in Flores v. Arizona
}

\author{
MELINDA HOLLIS THOMAS, DINNY RISRI ALETHEIANI, \\ DAVID LEE CARLSON \& ANN DUTTON EWBANK \\ Mary Lou Fulton Teachers College, Arizona State University, Tempe, USA
}

\begin{abstract}
The authors' purpose in this article is to interrogate the mediated and political discourses that emerged alongside the Flores v. Arizona case. The authors endeavor to offer another voice, framework and approach that may help sustain a continuous, paramount conversation concerning the educational rights of English language learners and the ways in which the public rationalizes appropriate state provisions for such students. Therein, the manuscript operationalizes the rationalities that appear across pro-Flores data (which consists of public opinion rhetoric positioned in support of the plaintiff and therefore in favor of appropriate state support for English language learners). The analysis of this data lays bare the echoes of the discursive regime surrounding the Flores case, a regime which unmasks neo-liberal rationalities for supporting English language learners. For example, the findings indicate that neo-liberal rationalities such as commodification, competition, risk, security, insurance and entrepreneurialism dominate the discursive landscape and eclipse alternative ways of arguing in support of students' rights to equitable and appropriate education, including social justice, pluralism and democracy.
\end{abstract}

\section{Introduction: two tales}

In the first weeks of the year 2012, Arizona's Tucson Unified School District (TUSD) once again made national news with an 'extraordinary ban on books' (Biggers, 2012). While the use of the term 'ban' to characterize the forced removal of specific texts from TUSD classrooms may be questionable [1], the events of January 2012 serve as a noteworthy follow-up to House Bill 2281 (State of Arizona, House of Representatives, 2010), which forbids Arizona public schools from offering classes that 'promote the overthrow of the United States government [or] resentment toward a race or class of people', or are designed for 'pupils of a particular ethnic group' or 'advocate ethnic solidary' (H.B. 2281, 2010, lines 12-16). Specifically, the bill targets the elimination of academic programs that feature Mexican American and Indigenous history, the work of Mexican, Latino, Chicano and Native American writers, or have 'race and oppression as a central focus' (Acosta, quoted in Biggers, 2012). The official curriculum audit and book 'confiscation' followed in the footsteps of Arizona's now infamous Senate Bill 1070 (Arizona v. United States, 2012), a law described as 'the broadest and strictest anti-illegal immigration measure in recent US history' (Rios-Aguilar \& Gándara, 2012, p. 5). Senate Bill 1070 is particularly contentious and connected to House Bill 2281 in that it targets Latino people, providing Arizona authorities with permission to racially profile and detain any person who they think may be an undocumented immigrant.

In a district with at least $60 \%$ of its students hailing from Mexican American backgrounds, books on the TUSD banned list were seized from classrooms and from students and placed in storage. Teachers were warned to adjust their curricula and their methods accordingly, lest they wished their jobs to be threatened and their district to lose approximately US\$15 million in funding 
per year (Ordoñez, 2012). Students from Cholla High School who protested against the ban were punished with 'janitorial duties' (Rodriguez, 2012). Clearly, the First Amendment, students' and teachers' rights to engage 'controversial' topics and ways of knowing in the classroom, cultural pluralism (Rowe, 2000; Butler, 2001) and the notion of social justice (Delpit, 1995; Delpit \& Dowdy, 2004) all seem to be going up in flames. As with Senate Bill 1070, the rights of Latino, Mexican, Chicano and Indigenous Americans are positioned at the ignition point.

Maybe the dystopian worlds of Margaret Atwood's (1985) The Handmaid's Tale and Ray Bradbury's (1967) Fahrenheit 451 are closer to our own than we ever imagined. While the books in question are boxed away in Tucson closets rather than deposited in a fire, a literary metaphor seems an appropriate way to contextualize the complexities of the logic that surrounds Arizona's public education system. Alongside confiscating books and eradicating disciplines, this logic includes a consistent failure to fund appropriate language programs for students who do not speak English as their first language. The TUSD book confiscation, one of Arizona's current trials and tribulations, sets the stage for another trial that is still unfolding, albeit more dormantly, in the Arizona public school system - Flores v. Arizona (1992, as reported by Arizona Senate Research Staff, 2008). Like the TUSD confiscation, the Flores case and the rhetoric that emerged around it present a story laced with discourses regarding who should learn, what they should learn, with what resources and for what purpose. In the scope of this article, we examine pro-Flores public opinions and find that the rhetoric therein is punctuated by neo-liberal rationalities, denoting a particular imperative by which to lay claim to the English language and its purported promise for English language learners (ELLs) across the state.

\section{Overview of the Article}

For contextual support, we first discuss Arizona's demographic data as it intersects with the landscape of language policy; we then provide a brief legal and legislative history of the Flores $\mathrm{v}$. Arizona case. After we briefly describe our data collection methods and review recently published scholarship on the case and its consequences, we then situate the reader within neo-liberal rationalities of rule to discuss the relationship between this framework, the Arizona public school system and the Flores case. In order to understand the complexities of this case and its importance to language policy in Arizona and in other states, we investigate public opinion - the political and the mediated rhetoric that surrounds Flores v. Arizona - in subsequent sections, with analytical eyes on the neo-liberal ideologies that abound.[2]

Interlaced with the theoretical framework, which seeks to unmask neo-liberal regimes of truth, the data analysis illustrates ways in which the English language is positioned as an ideological commodity in a neo-liberal state - English fosters competition, reduces risk, provides insurance and produces entrepreneurial subjects. The analysis operationalizes pro-Flores documents in our data set. Across the pro-Flores documents, we find that neo-liberal rationalities - commodification, competition, risk, security, insurance and entrepreneurialism - dominate the discursive landscape that is, proponents for addressing the educational needs of ELL students harness neo-liberal discourses to rationalize and justify their support of language policy and funding reform. In the conclusions, we are left to consider neo-liberal discourses too in light of what they are not, and what they silence or marginalize. Our data indicates that considerations for social justice, pluralism and democracy are wholly absent in the discursive landscape we examined. After we weave together the case with our theoretical framework, data, discussion and analysis, we will open an incendiary text that may provide some metaphorical closures and conclusions based on what the 'unsaid' suggests and may compel us to do next.

\section{Arizona Demographics before, during and after Flores}

While all US states are constitutionally obligated to provide free common schools, shifting demographics, fiscal structures, ideologies and social conditions create tensions in the schooling of the citizenry. Increases in immigrant populations and students who are ELLs present unique challenges to US public school districts. Scholarship in the area of bilingual education focuses primarily on methods of teaching language acquisition to ELL children. Some scholarship has 
focused on practices to aid second-language learners with academic proficiency (Wong-Fillmore $\&$ Snow, 2000), while others have argued that ELL students need longer instructional time (Gold, 2006) or social supports from schools (Gándara \& Rumberger, 2009). Finally, research on the detrimental effects of student segregation based on student poverty, ethnicity, race and language background (Balfanz \& Legters, 2004; Borman \& Dowling, 2010) illustrates a need to counteract policies that increase segregation or deepen its effects (Berends \& Peñaloza, 2010; Gándara \& Orfield, 2012). Regardless of what academic research shows, funding for bilingual programs remains in the hands of state legislatures, even though 'relatively little direction has been given to states as to how to effectively educate their immigrant students despite a growing body of research evidence' (Gándara \& Rumberger, 2009, p. 766).[3] Discrepancies between federal laws and state practices seem inevitable, as states must temper federal guidelines with attempts to remain financially responsible and solvent. Moreover, ideological battles between political parties have further complicated an always urgent, yet murky situation for most states.

A pressing need for viable funding solutions for appropriate language education is perhaps more visible and prevalent in the state of Arizona because the ELL population has grown considerably over the past 20 years. According to the Morrison Institute for Public Policy's 2012 report Dropped? Latino Education and Arizona's Economic Future, between 2001 and 2010, Arizona's Hispanic population grew by $17.3 \%$. Latinos now comprise nearly one-third of the state's population and about $47 \%$ of its children under 19 years of age. Nearly $100 \%$ of Hispanic children under the age of five are US citizens. Compared to a US average of $20 \%, 27 \%$ of Arizona's residents speak a language other than English in their homes (US Census Bureau, 2012). Arizona is expected to become a 'majority-minority' state within perhaps two decades, and Latinos will constitute the majority. The purpose of the Dropped? report is to offer an in-depth update on the state's response to a 2001 research report.[4] A decade after the initial report, the Morrison Institute for Public Policy (2012, p. 10) found that: 'Arizona's Latinos - our fastest-growing population group continue to display substantial shortcomings in educational performance levels, lagging well behind the state's White population'. In short, the achievement gap has not changed significantly since 2001, yet the population of ELL students continues to grow.

Another population trend that arranges Arizona's future prospects in compelling ways is the age gap between Latinos and white citizens. A majority of the white population is 45 years or older, and the greatest proportion of those people is 70 years or older. Yet, the greatest number of Latinos is 40 years or younger. Arizona's age demographics highlight the effects of decades of crippling tax policies for public expenditure. As Glass (2008) points out, older white populations oppose paying taxes for public services for Latino children. Decades of conservative income and business tax policies in Arizona have produced millions in deficit spending (Altheide \& Johnson, 2011). In response, the state continues to slash public education expenditures [5], including ELL instruction, while data on educational attainment indicates that Latinos continue to fall behind their white classmates (Morrison Institute for Public Policy, 2012). The Flores case emerged amid the legislative, economic and educational landscape described above.

\section{Flores v. Arizona: legal and legislative history}

In 1992, Southern Arizona Legal Aid filed a class-action lawsuit in the Federal District Court on behalf of parents and their children in the Nogales Unified School District. The plaintiffs in Flores v. Arizona argued that Arizona schools failed to provide instruction for ELL students [6] that supported proficiency in English and enabled students to master the standard academic curriculum. This ruling was the beginning of a lengthy legislative and legal battle that led to the hearing of Horne v. Flores in the US Supreme Court in 2009. The case continues to be disputed in lower courts to this day.[7]

Miriam Flores, who is now in her twenties, is the central figure in an ongoing court battle over the provision of English language learning in the state of Arizona. Miriam grew up speaking Spanish at home. She began to fall behind her peers when her bilingual classes ended in the third grade. Her mother, also named Miriam Flores, noticed that her daughter's grades dropped considerably. Miriam's teacher called Mrs Flores to report that Miriam had not been paying attention and had been chatting during class. When Mrs Flores asked Miriam about her teacher's 
concerns, Miriam replied that she was asking her classmates to help her understand what the teacher was saying. Discouraged, Mrs Flores and other parents of children enrolled in the Nogales Unified School District brought forth a class-action lawsuit alleging that the civil rights of ELL children were being violated because the state of Arizona failed to provide instruction that included funding for ELL students, adequate English language acquisition and appropriate academic programs.

In 2000, District Court judge Alfredo Marquez ruled in favor of the plaintiffs and stated that Arizona's ELL programs were in violation of the federal Equal Educational Opportunities Act of 1974, a result of the 1974 Supreme Court case Lau v. Nichols.[8] In the scope of the ruling, while Arizona ELL programs were based on sound educational theory, the funding level for English learners was deemed 'arbitrary and capricious' (Arizona Senate Research Staff, 2008, p. 2). Relatedly, the judge ruled that Arizona failed to provide enough teachers, teachers' aides, classrooms, materials and tutoring for these students. The state did not appeal judge Marquez's decision.

Arizona superintendent of public instruction Lisa Graham Keegan then entered into a consent decree with the plaintiffs.[9] While the consent decree addressed program adequacy, it did not address the judge's concerns about funding. The same year, Arizona voters approved Proposition 203, which eliminated bilingual education in Arizona. Bilingual education programs were thereafter replaced by Structured English Immersion (SEI) programs for ELL students, except in cases where students were fully proficient in English and signed a waiver. SEI programs deliver all materials and curriculum in English, with minimal use of students' native languages, for a period not to exceed one year.

Concurrent to the elimination of bilingual education in Arizona, the Federal District Court ordered the legislature to conduct a cost study in order to determine the amount of additional funding needed to support the SEI mandate. The court set a completion date of January 2001 so that the results of the cost study could be used to guide the correction of funding deficiencies for SEI programs during the next legislative session. The cost study was not completed until May 2001 and suggested a range of US\$0-4600 additional funding per ELL student. Yet, it too did not provide any specific recommendations. The publication of this cost study was followed by a series of challenges, responses and mandates that, for our purposes, are best truncated and summarized in a table (see Table I).

\begin{tabular}{lll}
\hline Date & Action & Response \\
\hline June 2001 & $\begin{array}{l}\text { District Court ordered state compliance with January 2000 } \\
\text { ruling, setting a due date of 31 January 2002. }\end{array}$ & $\begin{array}{l}\text { Arizona legislature convened a } \\
\text { special session in late 2001. }\end{array}$ \\
December 2001 & $\begin{array}{l}\text { Arizona legislature approved House Bill 2010, which } \\
\text { increased ELL funding to US\$340 per pupil. }\end{array}$ & $\begin{array}{l}\text { In April 2002, the plaintiffs } \\
\text { challenged the funding level. The } \\
\text { District Court ordered another cost } \\
\text { study. }\end{array}$
\end{tabular}

August 2004- National Conference of State Legislatures conducted a February 2005 cost study that recommended US\$670-US\$2571 per pupil.

December 2004 Plaintiffs filed a motion with the District Court requesting a deadline be established for compliance.

January 2005

District Court ordered state compliance for ELL funding.

May 2005

December 2005

January 2006
Arizona legislature passed House Bill 2718, which included the organization of a task force and increased funding for ELL students.

District Court ordered progressive daily fines until state compliance.

Arizona legislature passed Senate Bill 1198, which was similar to House Bill 2718 but also included the
A plaintiff motion followed.

A District Court order followed.

House Bill 2718.

Governor Janet Napolitano vetoed the bill.

Senate Bill 1198.

Governor Janet Napolitano vetoed the bill and called the legislature into 
establishment of income tax credits for contributions toward scholarship and tuition grants for private schools.

January 2006

Arizona legislature passed House Bill 2002, which was identical to Senate Bill 1198, but included a cap on corporate income tax credits for private school contributions.

March 2006

Arizona legislature passed House Bill 2064, which was like House Bill 2718, Senate Bill 1198 and House Bill 2002, but excluded tax credit provisions and increased per-pupil funding to US\$432. a special session.

Governor Janet Napolitano vetoed the bill.

Governor Janet Napolitano allowed the bill to become law without her signature. It became effective in September 2006, with the exception of the funding increase.

By this time, the state had accumulated US\$21 million in fines set forth by the District Court in December 2005.

March 2006

April 2006

August 2006
District Court ruled that the US\$21 million accrued in fines should be distributed to school districts and that ELL students should not have to take the AIMS [10] as a graduation requirement until appropriate funding was determined and allocated.

District Court ruled that House Bill 2064 did not satisfy the 2000 Flores ruling.

Ninth Circuit Court of Appeals denied the District Court's assessment of fines, removal of the AIMS graduation requirement, and rejection of House Bill 2064. It requested an evidentiary hearing to determine if changes in the educational landscape suggested modifications to the 2000 decision.
Superintendent and Arizona legislature appealed the ruling to the Ninth Circuit Court of Appeals.

In the meantime, the Arizona English Language Learners Task Force (authorized by House Bill 2064) developed and reviewed SEI models and their costs. The 'four-hour block' [11] is a required part of SEI programs for all first-year ELL students. In determining costs and creating budget forms, the maximum funding provided could not exceed the total amount allocated for Group B funding, Title I, II and III impact dollars, and any desegregation money allocated to the school.

September 2007 Task Force formally adopted SEI models that included: the four-hour block annual entry/exit classification through the task force's AZELLA [12] assessment student grouping by overall proficiency level within grade class size targets of 20-28 students

November 2007 Task Force adopted a budget form developed by the Arizona Department of Education to fund SEI.

March 2008

Arizona Department of Education reported that public schools requested US\$274.6 million in funding for SEI; approximately US\$90 million were 'approved'. It then subtracted the funding required by House Bill 2064 to determine that only US $\$ 40.7$ million in funds would be distributed.

Arizona legislature passed Senate Bill 1096, approving the US\$40.7 million to fund the Task Force models.
Governor Janet Napolitano allowed the bill to become law without her signature. 
June 2009 Supreme Court ruled on Horne v. Flores, 129 S.Ct. 2579.

2010-11

March 2013

Ninth Circuit Court of Appeals ruled on Flores
Court ruled in favor of Horne 5-4; reversed District Court rulings; remanded case back to district court.

Superintendent Tom Horne and the President and Speaker of the legislature defended the four-hour SEI requirement.

Judge Collins vacated the original judgment and upheld Arizona's ELL programs.

April 2013 Center for Law in the Public interest appealed the decision to the Ninth Circuit Court of Appeals.
The Center's opening brief was due in August 2013.

Table I. Activity following Flores v. Arizona decision, 2001-2013.

Source: The data from this table were derived, in part, from the Arizona State Senate Issue Paper, 2008.

Most recently, the Ninth Circuit Court of Appeals contended that the funds allocated by the legislature were 'arbitrary and capricious', yet it upheld the four-hour SEI instructional model. The state then appealed to the US Supreme Court. The Supreme Court heard arguments in Horne v. Flores on 20 April 2009. In June 2009, the Supreme Court decided five to four that the case be remanded back to the lower court, asking it to assess academic progress according to adjustments made by the state in both instructing ELL students and funding programs. The case is currently in litigation once again in the Ninth Circuit Court of Appeals.

Scholars have since begun to discuss the lasting effects and future implications of the Supreme Court decision in terms of the impact on students in Arizona and the precedent that this case law sets for other states. According to the Horne v. Flores decision: 'Research on EL instruction indicates there is documented academic support for the view that SEI is significantly more effective than bilingual education' (Horne v. Flores, 2009, Majority Opinion, p. 24). However, Martinez-Wenzl et al (2012, p. 26) found that there is 'no evidence' for the court's decision; in fact, at best, with sound implementation, SEI is no better and no worse than other forms of instruction, particularly bilingual instruction. Unfortunately, Arizona's discrete approach to SEI 'carries serious negative consequences' because of its limited focus on English instruction, to the detriment of the gradelevel academic curriculum (Martinez-Wenzl et al, 2012, p. 1). Further, the court's decision arguably legitimates ethnic segregation and the denial of core academic content to ELL students, as long as the requirements of the Equal Educational Opportunities Act of 1974 [13] are otherwise met (Gándara \& Orfield, 2010; Rios-Aguilar \& Gándara, 2012).

\section{Data Sources}

In order to begin to glimpse the discursive underpinnings of the Flores case and rulings, we analyzed public and political commentary related to ELL program funding and the case published in the peak years of the hearings. In order to collect data sources, we conducted keyword searches that included 'Horne v. Flores', 'Miriam Flores', 'Flores v. Arizona' and 'Speaker of the House of Representatives v. Flores' in publications between the years 1992 and 2009. The databases used to pool the data from the keyword searches included Academic Search Premier, Access World News, Ethnic Newswatch, LexisNexis Academic, Proquest and the Education Resources Information Center. The data sources, including newspaper articles, opinion letters, newspaper op-ed columns, policy institute websites and legal documents (including case law and law reviews), were then placed into four main categories (detailed below). Governmental press releases and policy statements from Arizona's governors and superintendents of public instruction and the Arizona Department of Education website were also examined and categorized.

The data sources were read and then sorted into four major categories, based on the majority of their commentary or quoted material: 
1. Pro-Horne (Arizona superintendent) - data in this category upholds fiscal restraint and supports the legislature's decision to fund (or not fund) ELL programming.

2. Pro-Flores (plaintiff) - data in this category argues in favor of adequate funding for ELL students and ELL students' rights to education.

3. Minimal commentary - data in this category contains minimal commentary on or reference to the case, or the data is related to the case only extraneously.

4. Unrelated or unclear perspectives - data in this category may pertain to educational methods rather than funding.

For the purpose of this article, we discuss the documents categorized as pro-Flores. Thirty-two texts met the pro-Flores criteria. Eight of these texts are university law reviews or scholarly journal articles, and we did not use them in this study, as we believe them to constitute academic research rather than public opinion. The remaining 24 documents are press releases, interviews, congressional hearings and newspaper articles, 20 of which are cited directly in this study. We focus on this particular set of documents (pro-Flores) because of all the mediated, public, mainstream rhetoric collected, the speakers and authors who supported the plaintiff revealed discourses that reflected the importance of funding ELL programs, including the logic behind their support. Our findings in this data set illustrate an array of neo-liberal rationalities for funding ELL students, but hardly any mention of social justice, pluralism or democracy as issues to consider or virtues to uphold in themselves (Apple, 1995; Smitherman, 2004; Brooks \& Thompson, 2005; Ayers, 2006). We focus on only pro-Flores documents with an understanding of the limitations of this data; the larger data set provides rich context for the study as well.

We also acknowledge that our examination of neo-liberal rationalities in the pro-Flores data provides but one of many approaches to theorizing the condition of the Arizona school system in the shadow of Flores v. Arizona and the plight of the students who currently attend Arizona public schools. Teachers College Record recently published a special issue that compiled myriad noteworthy studies, many of which are the revised results of data reports submitted to the office of the Civil Rights Project at the University of California, Los Angeles in 2010 in response to the Flores v. Horne Supreme Court ruling. For example, Lillie et al (2012, p. 27) activate a political trajectory lens to problematize practices that result from the Flores ruling, which sustain 'real and perceived' divisions between ELL students and their non-ELL peers. Several studies in this special issue explore the segregationist consequences of the Flores ruling (Gándara \& Orfield, 2012; Lillie et al, 2012; Martinez-Wenzl et al, 2012; Rios-Aguilar \& Gándara, 2012). What is more, Lillie et al (2012, p. 28) argue that, alongside the Flores ruling and the system's embrace of SEI, Arizona's eradication of compensatory education and summer school may act as a 'blatant violation of Lau v. Nichols (1974)' because ELL students enduring the SEI model have no way to catch up with their peers in mainstream classrooms. Garcia et al (2012) employ historical research and descriptive comparisons to illustrate trends in the academic outcomes of ELL students. Rios-Aguilar et al (2012a, p. 17) examine 880 teachers' perceptions of SEI programs to argue that SEI is ineffective and provides 'little or no acceleration of students' English language proficiency'. In line with Rios-Aguilar and Gándara's (2012, p. 6) claim that contexts and discourses outside of the law and scientific research alter the legal process, 'including the political context ... and the media', we offer another voice, framework and approach to help sustain this continuous, paramount conversation by displaying some of the echoes of the discursive regime.

\section{Neo-liberal Rationalities of Rule}

The obligation of the state of Arizona to provide adequate and equitable education to its citizens illustrates a direct link between legislative policy and the everyday educational experiences of students in public schools (Bratsis, 2006). Negotiations between political parties over how best to allocate resources and funds to schools in order to meet the demands of growing immigrant populations reflect the state's priorities and, perhaps more importantly, their particular views of the role of government. Ostensibly, it seems rather appropriate for members of the state legislature to allocate necessary resources to public schools that cater to a high immigrant population. From a social justice perspective, one might argue that promoting researched-based bilingual education in 
these schools is also a moral imperative (Zollers et al, 2000; Delpit \& Dowdy, 2004; Smitherman, 2004).

Political theories inform particular approaches to how to properly educate children in Arizona schools. The discourses and rationalities used to discuss the purposes and uses of language policy in Arizona indicate that neo-liberal rationalities of rule dominate the discursive landscape. The data collected for this study narrates neo-liberal rationalities of rule that foster and promote competition, deregulation and new prudentialism (Dean, 2009) - a term to describe the role of government in terms of the individual's responsibility to manage his/her own risk and insurance in order to produce entrepreneurial subjects. The state of Arizona's rationalities of rule do not simply dictate and audit educational practices; they arrange learning spaces that propagate neo-liberal mentalities of entrepreneurialism among immigrant students. This section provides an explanation of the main attributes of neo-liberalism to set the stage for the ways that neo-liberal rationalities play out in the discursive landscape surrounding Arizona's language policy.

Neo-liberalism has become the dominant ideology in the USA. Its promise of individual choice, personal liberty and flexibility, coupled with the economic principles of privatization, deregulation and free enterprise, has captured the political discourse for over 30 years. As Peters (2005, p. 126) points out, rationalities of neo-liberalism emerge from 'two competing tendencies state centralization and a logic of dispersion'. The problem and allure of neo-liberalism are the same: governing or managing populations while promoting individual liberty. In contrast to previous centuries (most notably the sixteenth), governing in the twentieth century involved 'governing at a distance' instead of government by the guillotine.

Classic liberalism resulted from a distain for the heavy hand of raison d'état regimes. More recently, the Great Depression and subsequent social welfare programs of the New Deal, along with the rise and fall of the Weimer Republic and the Third Reich, problematized government's role in shaping society. The decline of social democratic and totalitarian governments necessitated a compromise between labor and capital in order for inter- and intra-state peace to exist. However, some intellectuals disapproved of the increased role of the state in managing social, economic and political relationships. They advocated for the reverse, which meant policies that removed the state from interfering in socio-economic affairs.

Neo-liberalism developed in approximately 1947 with the foundation of the Mont Pelerin Society, a response to the political fallout of the Second World War in Germany (Peters, 2001). The work of Friedrich von Hayek (1944) influenced the work of the society. While the Society maintained the principles of classical liberalism (Gordon, 1991; Peters, in Peters et al, 2008; Dean, 2009), they made two important distinctions. First, they argued that knowledge about a population or individuals within a population is limited. In other words, they argued for the principle of selective communication or the idea that knowledge is always restrained by competing and contingent factors - not everything can be known all of the time and some pieces of knowable information have to be selected. Second, they contended that economic theories and principles can be metaphorical guides to understanding all human behavior (see Becker, 1964). In contrast to other theories of human phenomena and behavior (i.e. psychological or sociological), neo-liberals maintain that human beings are driven by personal self-interest as they make everyday decisions and life choices. These ideas shaped the US form of neo-liberalism that would become commonplace in the late 1970s (Harvey, 2005).

It was the work of the Chicago School of Economics, initiated by the work of Milton Friedman, that would shape political economics for the last three decades of the twentieth century, and arguably the first two decades of the twenty-first (Peters, 2001; Giroux, 2008). Proponents of this version of neo-liberalism support policies that strive to drain governmental expenditures of entitlement programs, welfare institutions and social safety nets in order to buttress the private sector. This view was perhaps most popularized by Margaret Thatcher (1987), the former prime minister of the United Kingdom, who declared: 'There is no such thing as society'. Therein, public programs are sacrificed for the benefit of private industry and the business community; social security, public education and healthcare would be managed better and more efficiently if they were in the hands of private companies. Additionally, neo-liberals contend that individuals can decide for themselves how to spend their retirement, how to manage their health care, and how to educate themselves and their children (Burchell, 1996). 
In effect, neo-liberalism seeks to deregulate the private sector in order to let the market determine value. Policies and practices follow a market-driven mentality in which the whims of supply and demand dictate who gets what, how much, how often and at what cost. Commodities, then, are not just items such as coffee, corn and cotton; commodities are also concepts like ideas, language, persons and information. The pursuit of access to these concepts becomes part of the neo-liberal political scheme; language, for instance, is no longer taken for granted or administered by the government as part of what is necessary to be productive and able citizens. Instead, language is left to the competitive market, a place where individuals and groups have to battle with each other for access.

While the practices of neo-liberalism vary slightly, there are some common themes that distinguish it from other forms of governance. Perhaps the most important feature of neo-liberal rationalities is entrepreneurialism. Entrepreneurialism can be broadly defined as one's personal initiative to be responsible for one's present and future financial, personal, mental and spiritual well-being. Individual success in a neo-liberal state is associated with entrepreneurial abilities. Further, neo-liberalism celebrates and protects private enterprise, claiming too that the privatization of welfare institutions (for example, health care, education and social security) would be more efficient and more effective if they were placed in the free hands of the market. Similarly, government deregulation of businesses, banks and corporations allows the free market to flow, producing jobs, innovation and investments. Finally, competition can determine the best solutions to major social problems. Neo-liberalism produces 'artificially arranged or contrived forms of the free, entrepreneurial and competitive conduct [of the] economic-rational individual' (Barry et al, 1996, p. 23).

Neo-liberal rationalities of rule convert virtually everything into a commodity, including language, in order to foster competition with the intention of producing an entrepreneurial subject who is capable of managing his/her own risk. As Donzelot (2009, p. 22) explains, the shift from raison d'état states in which the quantification of the population as a viable resource for the sovereign shifts to one of political economy, the quality of the population transforms into a managed substance based on 'extant resources, which depend on the development of trade between individuals as well as countries'. Governing populations, rather than regulating them, focuses on the interplay between human beings rather than dictating or trying to dictate their actions (Donzelot, 2009).

The story of governance and the population is therefore no longer told from the perspective of the state; instead, governance plays out in the market. Relegating human beings to the marketplace forces a limited role of the state but expands the nature of self-governance. Put another way, the continual critique of the state's role in the affairs of human beings unleashes rationalities and practices of governance based on market economic theory, which compels human beings to manage themselves in relation to others. In neo-liberal terms, the market fosters competition more so than exchange. The exchange of goods based on fair prices and wages means less for an effective and secure state than demarcating spaces of free competition. As such, inequality becomes a sine qua non of a neo-liberal state and, rather than relying on state intervention to reallocate resources from excesses or insufficiencies, the state instead needs to adjust market forces to generate competition based primarily on inequalities.

Competition fosters inequality, and vice versa. Competition thus becomes an eidos, or a formal mechanism of 'equal inequality' (Donzelot, 2009, p. 24), in a neo-liberal state. The neoliberal state promotes

anything that shares the spirit of the enterprise and relies on men as entrepreneurs of economic activities as well as of themselves ... as members of a collective regarded like an enterprise of coowners taking care of maintaining and increasing the value of their goods. (Donzelot, 2009, p. 25)

Social policy, thus, does not ameliorate social inequalities a priori to offset inequalities; it buttresses the rationalities of competition.

The subject of neo-liberal governance is the entrepreneur. As the state of Arizona transforms the English language into a scarce commodity and compels students to compete for access to it, the state exercises neo-liberal political practices, specifically in its desire to drain the welfare state, promote new prudentialism and produce entrepreneurial subjects who will allegedly outgrow dependency on the state as a 'nanny' and its provisional 'safety nets'. Under neo-liberal governance, 
the responsibility of education, health, employment and retirement shifts from the state to the individual. Governmental policies that extend welfare, neo-liberals proclaim, promote risky behavior and dependence on the state. Therefore, shifting risk and insurance to the individual compels individuals to be more prudent in their actions, plan for their futures and exercise choice to determine the course of their lives. The responsibility of learning English now belongs to the individual as well; the well-heeled subject will compete for it, invest in it, attain it, master it and exchange it for other commodities the state need not provide.

\section{Neo-liberalizing Arizona}

When addressing the purpose of education in Arizona, a neo-liberal consensus abounds. Our data shows that politicians and congressional members agreed that proper education would produce a viable workforce, one filled with students ready to compete in a globalized economy (Scribner, 2005; Napolitano, 2006). The contested areas centered primarily on the role of the government in providing equitable education for all students. The role of school finance and resources delimited much of the political debate, as did decisions on how to distribute resources to schools. Throughout the discourse, neo-liberal trends and outcomes continued to surface. The Arizona Education Association reported on 10 October 2007 that: 'Irresponsible tax cuts for big businesses and top income earners in Arizona have cost the state funding that would offset current inadequacies in Arizona's current investment in K-12 students'.[14] The intersection between public and private entities, specifically on tax policy, proved crucial to the debate on the legislative role in adequate and fair funding for public education. Low tax rates and tax credits for corporations defund public education and, as Glass (2008) notes, ultimately harm low-income and immigrant populations. The same can be said of charter schools, and Arizona houses the greatest number of charter schools per capita in the USA (Center for Education Reform, 2011).

Republicans in Arizona's state legislature tried to pass each of their four Flores response bills to address the adequate funding for ELL students in Arizona with provisions for tax credits for corporations, by diverting Title I funds from the public schools which received the additional monies, and by attempting to initiate an educational voucher program in the state. In 2006, the Arizona Republic reported that:

The Legislature's proposed Flores resolution demanded low-income communities transfer federal poverty money to English-language learners before receiving any state dollars and tried to sneak in a corporate tax credit for English programs at private schools. But unlike their public school counterparts, there is no accountability enforcement. (Wells, 2006)

These resolutions show that schools which service a higher ELL population should compete with schools that serve a high number of students with low socio-economic status. Further, private schools, like charter schools, garner benefits not given to public schools. In short, the Arizona state legislature would defund public schools with high-needs students and high immigrant populations in order to siphon money to private schools. Furthermore, private schools under these resolutions would be granted monies without fiduciary responsibility and accountability, in essence giving private schools carte blanche. Private schools would get unrestricted state funds, while public schools would have to divert federal aid and show how the funds would be used to help ELL students. Public schools would be required to take money allocated for Title I students and give it to immigrant students, which would generate a moderate net increase in actual funding dollars.

Privileging the private over and at the expense of the public historically remains a prevailing discourse in the educational policy in the state of Arizona. Charter schools, voucher programs and the diversion of federal aid for ELL programs illustrate the preference of the private over the public. Additionally, these approaches in state educational policy represent neo-liberal attempts to drain the welfare state. They also reinforce the belief that public funds (even minimal amounts) should be used as judiciously and in as miserly a way as possible to educate Arizona's children.

Neo-liberal rationalities of rule relegate the social to the marketplace; hence, the idea is that students should learn to negotiate the marketplace. Legislators and politicians employed neo-liberal discourses to reach an agreement on how to satisfy the District Court's ruling that they provide a fair and equitable educational system. They established a space in which they encouraged students 
to negotiate a pedagogical marketplace designed for them to practice competing with others, assume their own risk and produce entrepreneurial selves.

\section{Risk, Security and Insurance}

Within neo-liberal rationalities of rule that foster competition above state intervention, notions of risk, insurance and security prove crucial to understanding the role of governmentality in the language policy in the state of Arizona. Insurance and risk exist as connected links in a matrix of 'abstract technology' (Ewald, 1991, p. 197). Abstract technologies do not necessarily exist in the real world; they are simply ways in which individuals and institutions relate to things and each other (Castel, 1991; Defert, 1991; Ewald, 1991). Conceptual insurance and risk get created based on the 'contribution of a certain imaginary' (Ewald, 1991, p. 198), some event or occurrence that may or may not happen but that hangs in the air and is operationalized in the discourse. Risk connects the probability or chance of the potential for peril or loss with the ability to recover loss or damages. It assesses probability, converts life into potential hazards, is based on populations and doubles as capital (Ewald, 1991). The calculus of risk projects the potential loss or harm of a certain event based on the individual's characteristics within a specific and similar population, though it usually cannot recover the exact loss or harm.

Likewise, insurance mitigates chance and ascertains the capital lost by a collective group; it is a financial and economic tool, but it is also a 'moral technology' (Ewald, 1991, p. 207). This means that chance events no longer control the livelihood of the individual. As Ewald explains:

Above all, [insurance] means no longer resigning oneself to the decrees of providence and the blows of fate, but instead transforming one's relationships with nature, the world and God so that, even in misfortune, one retains responsibility for one's affairs by possessing the means to repair its effects. (Ewald, 1991, p. 207)

Finally, insurance serves as a form of justice that competes with legal rights. It competes by making an individual's behaviors responsible for the collective, not just for the self. Social responsibilities replace the concept of natural rights and equity. Groups corral around specific interests, lifestyles, dispositions and behaviors, rather than a concept of unified man or society. Individuals can assume certain types of risk and acquire specific forms of insurance based on particular lifestyle goals.

By fostering competition, state policy forces individuals to be free to assume their risks and build their own forms of insurance without collective calls for the good of the social order. Defunding and deregulating the state's welfare institutions passes off risk and insurance from the state to the individual. Rather than relying on social welfare, individuals are now left to manage themselves, take their own risks, adjust their lifestyles and insure against risks in their own way in order to survive. By distributing risk and insurance, the state has fewer responsibilities, but it still manages populations by exposing them and forcing them into the marketplace.

Discourses of risk and insurance are prevalent in the discursive landscape surrounding language policy in the state of Arizona. In now common schooling parlance, the ELL population is said to be 'at risk' because of their poor language proficiency (Ramos, 2009). Language proficiency is one among many other important factors necessary for this category of students to pass courses in school. Consequently, ELL students are also said to be at risk of low academic performance in general (Flores, 2006), an argument highlighted by the case of a tenth-grader who had to pass a biology course taught in English, a language he did not speak (Judge Berzon, quoted in 'EnglishLearner Law Survives', 2008). Consider the following warning:

Going by 2007 test scores on the AIMS [Arizon's Instrument to Measure Standards], which is the standardized test students must take to graduate from high school, ELL students are far behind English-speaking students. For example, 33 percent of English-speaking high school students, which includes those in language programs for four or more years, failed the reading test.

Compare that with the 85 percent of all ELL students who failed the reading test. (Gassen, 2009)

The statement above puts ELL students at a higher risk than English-speaking students overall, but especially in academic terms.

Due to their high risk of participating in other, related risk-laden behavior - dropping out (Arizona Democratic Legislators, 2005; Trasvina, 2006) or going to prison (Wells, 2006) - the 
Arizona legislature views ELL students as 'a burden' (Scribner, 2005) on the state's educational system. Another individual risk is also related to immigration. Oftentimes, ELL students are likened to 'illegal immigrants' (Gassen, 2009) and, while this is not the case for the students in question, the label itself carries a great deal of additional risk. What is important to note here is that language - in this case English - is one big factor in determining risk. Therefore, governing the English language is a way of governing risk in a neo-liberal regime of rule.

Our data further identifies several concerns regarding the growth and future demographics of Arizona's student population. Public opinions point out that ELL students who were born in the USA become citizens of the USA (Uriarte, 2006). ELL students currently comprise about $20 \%$ of the public school enrollment in the state (Uriarte, 2006), and this number is increasing substantially each year (Flores, 2006). According to local newspapers, there are concerns surrounding the academic success, high school graduation rates, college attendance, and competitive and technological capacity to advance (Krikorian, 2006; Talton, 2006; Uriarte, 2006; Montini, 2009) within this entire population of students as it grows. If the state continues to bypass the need to address their academic achievement, Arizona will 'lose the human capital' (Talton, 2006) that its future depends on. Across the data, English language proficiency is linked to the discourse of the economic opportunities of the ELL population (Lexington Institute, 2009). 'Employable' qualities in future workers secure the nation's economy and improve the economic conditions of Arizona as a whole. In other words, ELL programs function as a state technology that removes the subjectivities of ELL students and their families from the burden of the state and replaces them as participating and contributing (useful) members of 'America's economic and social fabric' (Trasvina, 2006).

Risk, insurance and security also bring forth notions of individual and public health. Congressional testimonies surrounding the Flores case provide two health-related warnings: (1) English-only policies can hinder medical personnel's ability to 'communicate effectively with patients at federal or federally funded hospitals, potentially complicating diagnosis and treatment, or even facilitating the spread of communicable disease', and (2), from the ELLs' position, Englishonly policies can prevent them from 'seeking cost-effective preventive health care, leading to dangerous or expensive complications, or prevent parents from immunizing their children' (Trasvina, 2006). By this logic, individual health risks then extend to the rest of the population as well: 'English-only laws would undermine the federal government's ability to communicate with the public in situations where communication is urgently needed, thereby leaving all U.S. residents more vulnerable to danger' (Trasvina, 2006). English-only policies create a health risk when health institutions are unable 'to convey warnings or post danger or hazard signs in languages other than English' (Trasvina, 2006). There also exists a related risk for law enforcement officials when investigating crimes, communicating with crime victims or witnesses, and providing services against domestic violence and abuse (Trasvina, 2006). In this iteration, Trasvina (2006) also adheres to a discourse that places Spanish-speaking populations at high risk of committing crimes or becoming victims of, specifically, domestic violence and abuse. This type of risk is connected to one discussed above - the risk of imprisonment among ELL students.

\section{Entrepreneurialism Par Excellence}

Besley and Peters (2007) suggest that neo-liberal governance of welfare is often more manifest in moral regulation than in actual reductions in services and educational spending in many Western states. By contrast, we contend that dwindling state financial support and morality-based whims work to mutually reinforce each other in the neo-liberal conditions surrounding Arizona's ELL service provision. In Arizona, Spanish-speaking communities, families and children are left to shoulder a lack of appropriate state educational funding and fend for themselves while navigating sentiments of alleged linguistic inferiority (Gassen, 2009; Lexington Institute, 2009), educational deficits (Flores, 2006; Trasvina, 2006; Gassen, 2009), resentfulness (Uriarte, 2006) or unwillingness to master the English language (Trasvina, 2006).

All the while, the educational landscape is rigged so that certain students will succeed, others will not, and yet all will be held accountable for their own successes and failures. In this system, the English language takes on the attributes of a rare commodity to be consumed, preserved, reserved 
or withheld. And in a system of socially manufactured risk (Beck, 1992), in which those at risk without the 'right' language have only themselves to blame, the attainment of English, that golden commodity, is strapped to the concept of the emerging entrepreneurial subject/student/ community. In positioning English as a commodity, current educational policy and practices in Arizona foster competition to gain access to 'success' that is not available to specific demographics of students. The seeming scarcity of English in this system has a managing function, as it manages competition, encouraging ELL students to engage in self-creation through competition for and consumption of appropriate language education.

The state's response to Flores v. Arizona and the rhetoric that surrounds the case highlight lapses in state fiscal obligations that unfold alongside narratives of personal responsibility, selfgovernance, economic enterprise and competition, all in the service of promoting or sustaining entrepreneurial solutions to social problems. As funding for bilingual programs remains in the hands of the Arizona state legislature - a governing body that refused time and again to uphold court orders to allocate even adequate funds for ELL programming - fiscal redress and equitable education seem far on the horizon and even beside the point as far as the state is concerned. For instance, as litigation continued, the Arizona education system accrued US\$21 million in fines for failure to increase ELL funding appropriately (Arizona Senate Research Staff, 2008). While this failure to allocate adequate funding for appropriate ELL education is made real in economic terms, our data reflects beliefs that education bears the burden of annihilating the 'welfare state' in moral terms as well. A style of governance that promotes the development of the entrepreneurial subject is one of those terms.

Throughout the texts surveyed in this study, students are cast as entrepreneurial, 'responsibilized' subjects who will inevitably control the fate of their own success and prosperity, if they are offered choices that provide access to self-insurance and self-investment. Under neo-liberal ideology, state-sponsored education becomes a way station between child subjects to be managed and sovereign producer/consumer adult subjects who need not ask for anything from the government, including equitable treatment, because they can manage their own risk and have many choices by which to do so. Entrepreneurialism cultivates a kind of self-fashioning in which economic freedom is central, but political freedom is eclipsed (Peters, 2005).

The data contains narratives of the 'perseverance', 'ableness' (Uriarte, 2006) and 'desire and determination' (Trasvina, 2006) of members of the Latino community. The message is that Spanish-speaking students want to learn English and will learn English if allowed appropriate opportunities to do so while in school. When only inadequate 'sink or swim' (Ramos, 2009) provisions and programs are in place, students 'sink' in school and inevitably in society. One press release captured this sentiment as follows:

In too many American cities, children in bilingual education programs are far more likely to drop out of school than ever to become proficient in English ... until improving these poor success rates becomes an educational priority, such cycles of linguistic isolation will continue to imperil the real educational and economic opportunities for this crucial segment of our nation's population. (Lexington Institute, 2009)

In this narrative and others, educational opportunities in public schools carry over to economic opportunities after school for both the individual student and the entire demographic by which the student is categorized. Following a claim by Governor Napolitano, Scutari and Sherwood (2006) refer to public education as the 'best chance for these children to create a great life for themselves', as appropriate education 'gives them the skills and resources they need'.

The 'skills and resources they need' to do what, exactly? Across the data, the conclusion to this question is often cast in economic terms, as iterations convey a focus on education and its relationship to notions of 'investment', 'contributions', 'adding value', 'cost' and competition (Scribner, 2005; Krikorian, 2006; Talton, 2006). 'Investment' in ELL students, for example, is phrased alongside an economic contract or exchange, as supporting Spanish-speaking communities will be 'rewarding to Arizona for many years to come' (Flores, 2006). Another articulated goal is to 'invest' so that ELL children will become 'successful, contributing members of our community' (Krikorian, 2006) now and in the future, as '[t]oday's young Latinos will be entering their prime working years just when experienced employees will be needed to help replace the baby boomers' (Uriarte, 2006). The key focus here is on responsibilizing the student for the service of the state 
now and in the future on both economic and moral grounds. Appropriate language education is transformed into an insurance policy that pays out dividends in the 'American dream' (Uriarte, 2006), which could encourage 'the workforce and innovators to leapfrog beyond [Arizona's] unsustainable dependence on call centers, housing construction, tourism and retirement' (Talton, 2006). With appropriate education for ELL students, Arizona may set its sights on a 'viable workforce for the future' (Trasvina, 2006).

The iterations discussed above allow facets of 'enterprise culture', the appropriate context to cultivate the entrepreneurial subject, to shine through. Besley and Peters write that:

\begin{abstract}
The code words 'enterprise' and 'enterprise culture' are major signifiers in this new discourse, which emphasizes that there has been too much emphasis on social and cultural objectives and insufficient emphasis on economic goals in our education system. Henceforth, we must invest heavily in education as a basis for future economic growth by redesigning the system so that it meets the needs of business and industry. The curriculum must also be redesigned to reflect the new realities and the need for a highly skilled flexible worker who possesses requisite skills in management, information handling, communication, problem solving, and decision making. (Besley \& Peters, 2007, p. 171)
\end{abstract}

While some of the data highlights concerns about community culture, which seems paramount in discussions surrounding the language that children and their families use, culture too is often framed in entrepreneurial terms. One author remarks on the Fortune 500 desire for 'employees who are proficient in English and another language, and employees who understand American culture and cultures from abroad' (Scribner, 2005). Another author discusses the benefits of the 'diverse cultural laboratory of our own country', but only as it relates to the necessity to 'succeed as a nation both in international trade and in leadership for democracy' (Diehn, 2007). These sentiments go hand in hand with a critique of the welfare state as it is actualized through a fear of the failing ELL student.

Such messages convey the belief that students who are not given a chance in school will never become insured, efficient, entrepreneurial subjects. Instead, they will remain 'vulnerable' (Lopes, 2008) and join the ranks of a 'dangerous underclass' (Talton, 2006) who 'frequently drop out, instead, leading many toward a self-destructive path that often leads to prison' (Wells, 2006). Wells (2006) goes even further and pathologizes ELL parents for making poor decisions, for which state policy should not 'punish kids' in turn. These statements illustrate a cycle that upholds the neo-liberal belief that '[a]nyone can be ejected from the system at any time' (George, 1999) and that older generations pass down their natural unfitness and unequalness to their children. This logic is reflected in the data:

Kids who don't speak the language become adults who don't speak the language, people who

have a hard time finding and keeping jobs. They get into trouble. Go on welfare. They cost us a

LOT more than if we'd educated them properly. (Hogan, Flores Plaintiffs Attorney and

Executive Director of Arizona Center for Law in the Public Interest, quoted in Montini, 2009)

In its alleged ability to subvert reliance on a welfare state and encourage an enterprise society by scaffolding the creation of entrepreneurial subjects, language education clearly has a great burden to bear. Unfortunately, this focus on new prudentialism (Peters, 2005) in education simultaneously transfers risk and responsibility to individual children and their parents without acknowledging the realities of how neo-liberal practices actually sustain systemic barriers to equity. It also attempts to explain away the failure of subjects who cannot surpass barriers in an inequitable system for reasons that are integral to the design of the education system - that bastion of economic stability and success - in the first place.

\title{
Conclusions
}

Throughout this article, we have illustrated and analyzed what was 'said' through the pro-Flores public opinion documents collected. As a textual body, the data analyzed for this discussion is narrated by neo-liberal fantasies and rationalities of rule. Perhaps this is most noteworthy because these documents seemed as though they, of all the mediated rhetoric, would be most aligned to support the plaintiff and therefore the ELL student population that continues to seek educational 
equity through the appropriate allocation of state educational funds. But so much goes unsaid in and across these texts as well. There were but a few phrases that glimpsed other ways of framing the pro-Flores cause - for example, a few texts mentioned concern for honoring and embracing cultural differences (Arizona Education Association, 2007; Valdez, writer for The Arizona Republic, quoted in Diehn, 2007). Yet the sparse references to the gifts of pluralism were greatly outnumbered, trumped and eclipsed by the neo-liberal concerns surrounding ELL student subjects, as outlined throughout this article. Rather than position the English language as something that individuals or communities might not necessarily want or need, or even discuss equitable education as an issue of social justice, a moral imperative, part and parcel of democracy, and an indication of how we regard ourselves and others in a shared human society, the discussions in support of Flores hinge on issues of insurance, competition, marketable skills and the creation of the self as an entrepreneurial subject who must effectively produce, consume, survive and thrive within and without the state, yet always in its service.

In the shadowy present of Flores v. Arizona, now dormant for several years, we come full circle with the recent events in Tucson to question the purpose of education and the political function of withholding it. How else might we think about schooling in a state where books are banned, education is rationed, language is scarce, students, teachers and parents are left alone to fight for so few resources, and even the pro texts read like con texts if one reads both across and between the lines? Perhaps we can find some meaning together in a book that was banned in Pennsylvania and Wisconsin in 1974, in Washington state in 1994 (American Library Association, 2012), and in parts of North Carolina as recently 2013. Perhaps the book, Ralph Ellison's (1952) Invisible Man, was removed from these classrooms because of a threatening relationship between what children learn and what they may then do to seek justice and equity. In the spirit of 'keep[ing] up the good fight' (Ellison, 1952, p. 16), we would like to conclude by drawing together the plight of Arizona's students and the opening scene of the novel.

Ellison's unnamed protagonist thinks he has been invited to give a speech - at least that is what he was told. This protagonist is an intelligent young man who is haunted by his grandfather's deathbed advice to 'keep up the good fight' by extending kindness and deference to people who overtly hate, disenfranchise and oppress him, his family and other people who are not white. Therein, the protagonist wants nothing more than to perform 'desirable conduct' (Ellison, 1952, p. 17) by delivering a speech about the need for his people, black people, to 'cast down buckets' and exercise 'social responsibility' (pp. 30-31), in spite of systemic racial inequalities and in spite of the way he and his schoolmates are treated when they arrive at the town gathering on invitation. And give the speech he does, but first he must endure a brutal, blindfolded fight - the battle royal - with nine other young men, all for the entertainment of the town's white ruling class. Once the fight ends and the protagonist is the decided runner-up, he is then forced to endure the humiliation of trying to snatch coins from an electrified rug with his schoolmates while the sweaty, drunk, white gentry cheer and howl at them. At the end of these two battles, which could be cast metaphorically as peer-to-peer competition for approval to participate in white capitalism (the young men are all rewarded financially for entertaining the crowd), the protagonist is presented with his greatest reward of all - the opportunity to speak in public, a 'gleaming calfskin brief case' which he may fill with 'important papers that will help shape the destiny of [his] people' (p. 32), and a college scholarship.

The protagonist is, at first, elated with the result of the battle royal, even when he realizes that the 'gold' pieces he scuffled for on the electrified rug are fake. After all, he did what he was supposed to do - he competed as they forced him to and he delivered his speech, in spite of the blood forming in his punctured mouth and the audience's laughter at his accidental mention of 'social equality' instead of what he meant to say: 'social responsibility' (pp. 30-31). His family members congratulate him and he smiles at his grandfather's picture, satisfied with his accomplishment and unafraid. He fought the 'good fight' for the benefit of those who scorn him, and he arose as a victor. Yet, that night he dreams that the scholarship is not what it seems, that instead the briefcase - that symbol of his entrepreneurial potential, that container of economic and social promise, progress, prosperity and responsibility - also holds a letter, which reads: 'To Whom it May Concern ... Keep this Nigger-Boy Running' (p. 33).

The 'good' fight might not be so good after all. There is no justice in the protagonist's treatment and the nightmare that he must face because the briefcase holds but one version of the 
trappings of success, and that success will never really be his to embody, not if there is no support for his humanity, no care for the experiences he endures, no consideration for his ability to do anything but battle, or perform, or run. There is no justice in the pro-Flores perspectives examined here either, unless we begin to question why there is so much emphasis on the economic goals of our educational system - its 'equal inequalities' (Donzelot, 2009, p. 24) - but faint concern for humanity and justice. Could the money serve as a symbolic recognition of the need to support all students - a gesture to decades of scholarly research that shows, again and again, that ELL students have not received, and continue to not receive, adequate support? Perhaps rethinking the imperative to fight for appropriate provisions for all students and all people could behoove us to think about students as complex human beings and society as more than a manufactured quest to produce and reproduce entrepreneurial subjects in the service of a state that keeps them running.

\section{Acknowledgements}

The authors would like to acknowledge and thank Shayna Muckerheide for assisting in the data collection and categorization.

\section{Notes}

[1] The TUSD argues that the book confiscation is not actually a book 'ban'. While the books on the list are not allowed in classrooms and are not allowed to be taught in ethnic studies courses, they are available in several district school libraries. For more information, see Cambium Learning (2012).

[2] For example, the data collected reflects a relegation of the English language to a commodity to be fought for and possessed. Yet, we do not wish to argue that governmental forms of power/knowledge are akin to commodities. Indeed, we do not believe that Foucauldian notions of power/knowledge can be possessed. However, we do contend that commodification does happen, that commodities do exist and that such is not outside power relations - orientations toward commodities and competition have specific effects in neo-liberal states. In fact, neo-liberal rationalities of rule convert virtually everything into a commodity, including the English language, in order to foster competition with the intention of producing entrepreneurial subjects who are capable of managing their own risk.

[3] Gándara and Rumberger (2009) also cite August and Shanahan's (2006) Developing Literacy in SecondLanguage Learners: report of the National Literacy Panel on Language-Minority Children and Youth, as well as Educating English Language Learners: a synthesis of research evidence (Genesee et al, 2006), to further bolster this remark.

[4] The 2001 seminal research report Five Shoes Waiting to Drop on Arizona's Future discussed a need to harness the Latino population to advance the economic and social well-being of a state that is near the bottom in terms of educational expenditures, but is increasingly competing in the global marketplace. Of all of the five shoes waiting to drop in Arizona, the editors of the report indicated that the plight of Latinos in Arizona has reached a 'crisis' (Morrison Institute for Public Policy, 2001).

[5] The state of Arizona ranks forty-ninth in the nation with regard to per-pupil spending (MartinezWenzl et al, 2012). Further, per-pupil spending in Arizona decreased by $21.8 \%$ between 2008 and 2012 (Oliff et al, 2012).

[6] In a State Senate Issue Paper, the students are referred to as 'Limited English Proficient' or LEP until 2000, when they are reclassified as ELLs under Proposition 203 (Arizona Senate Research Staff, 2008).

[7] According to the Intercultural Development Research Association (2012): 'the case may be retired by the Federal District Court if the plaintiffs choose to proceed or some settlement on the case is not reached. No schedule has been set to date for follow-up deliberations'.

[8] The Equal Educational Opportunities Act of 1974 (1974) requires all public schools to provide ELL students with a program of instruction designed to foster competence in speaking, reading and writing English, while also enabling them to learn the standard academic curriculum provided to all students. This Act led to the establishment of Arizona laws that required school districts to provide specialized instruction for ELLs (US Department of Justice, 2012).

[9] The consent decree required several actions, including policies adopted by the Arizona Department of Education that would: standardize the identification of ELL students; create uniform performance 
standards for assessing and reassessing English proficiency; align the curriculum with instructional strategies appropriate for ELL students; require the Arizona Department of Education to assume compliance and monitoring duties; and provide criteria for individual education plans for ELL students (Arizona Senate Research Staff, 2008).

[10] AIMS is an acronym for 'Arizona Instrument to Measure Standards', a statewide standardized test.

[11] The 'four hour block' is a period of 'structured immersion' for four hours each school day in which students are to learn English pronunciation, grammar, and usage in English with other ELL students.

[12] AZELLA is an acronym for 'Arizona English Language Learner Assessment.'

[13] The Equal Educational Opportunities Act of 1974 (1974) requirements state that the state must 'take appropriate action to overcome language barriers that impeded [ELL students'] equal participation'.

[14] Additionally, Rios-Aguilar et al (2012b, p. 12) found that: 'Eighty five percent of ELC's [English Language Coordinators] consistently mentioned that funding is a strong concern for them because of the constant budget cuts'.

\section{References}

Altheide, D.L. \& Johnson, J.M. (2011) Living in Arizona: reflections on life in the tumultuous sunbelt, Cultural Studies $<=>$ Critical Methodologies, 11(4), 346-358.

American Library Association (2012) Banned and/or Challenged Books from the Radcliffe Publishing Course: top 100 novels of the 20th century. http: / www.ala.org

Apple, M.W. (1995) Education and Power. New York: Routledge.

Arizona Democratic Legislators (2005) Ruling in Flores Case Step forward for Arizona's Children. Press Release, 16 December. LexisNexis Academic database.

Arizona Education Association (2007) U.S. District Court Upholds Flores Order, State of Arizona Must Comply by March 2008. Press Release, 10 October. http:/ / www.arizonaea.org

Arizona Senate Research Staff (2008) Flores v. Arizona. Arizona State Senate Issue Paper, 27 August. http:/ / www.azleg.gov/briefs / Senate/FLORES\%20V.\%20ARIZONA.pdf

Arizona v. United States (2012) The Oyez Project at IIT Chicago-Kent College of Law, 7 December. http:/ / www.oyez.org/cases/2010-2019/2011/2011_11_182

Atwood, M.E. (1985) The Handmaid's Tale. Toronto: McClelland \& Stewart.

August, D. \& Shanahan, T. (Eds) (2006) Developing Literacy in Second-Language Learners: report of the National Literacy Panel on Language-Minority Children and Youth. New York: Lawrence Erlbaum Associates.

Ayers, W. (2006) The Hope and Practice of Teaching, Journal of Teacher Education, 57(2), 269-277. http: / / dx.doi.org/10.1177/0022487105285891

Balfanz, R. \& Legters, N. (2004) Locating the Dropout Crisis: which high schools produce the nation's dropouts, in G. Orfield (Ed.) Dropouts in America: confronting the graduation rate crisis, pp. 57-84. Cambridge, MA: Harvard Education Press.

Barry, A., Osborne, T. \& Rose, N. (Eds) (1996) Foucault and Political Reason: liberalism, neo-liberalism and rationalities of government. London: UCL Press.

Beck, U. (1992) Risk Society: towards a new modernity. London: Sage.

Becker, G.S. (1964) Human Capital: a theoretical and empirical analysis with special reference to education. New York: Columbia University Press.

Berends, M. \& Peñaloza, R. (2010) Increasing Racial Isolation and Test Score Gaps in Mathematics: a 30-year perspective, Teachers College Record, 112(4), 978-1007.

Besley, T.A.C. \& Peters, M.A. (2007) Subjectivity and Truth: Foucault, education, and the culture of self. New York: Peter Lang.

Biggers, J. (2012) Breaking: the 'madness' of the Tucson book ban: interview with Mexican American studies teacher Curtis Acosta on The Tempest, Huffington Post, 17 January. http: / www.huffingtonpost.com/jeffbiggers/tucson-ethnic-studies-_b_1210393.html

Borman, G. \& Dowling, M. (2010) Schools and Inequality: a multilevel analysis of Coleman's Equality of Educational Opportunity data, Teachers College Record, 112(5), 1201-1246.

Bradbury, R. (1967) Fahrenheit 451. New York: Simon \& Schuster.

Bratsis, P. (2006) Everyday Life and the State. Boulder, CO: Paradigm.

Brooks, J.G. \& Thompson, E.G. (2005) Social Justice in the Classroom, Educational Leadership, 63(1), 48-52. 
Burchell, G. (1996) Liberal Government and Techniques of the Self, in A. Barry, T. Osborne \& N. Rose (Eds) Foucault and Political Reason: liberalism, neo-liberalism and rationalities of government, pp. 19-36. London: UCL Press.

Burchell, G., Gordon, C. \& Miller, P. (Eds) (1991) The Foucault Effect: studies in governmentality. Hemel Hempstead: Harvester Press. http:/ / dx.doi.org/10.7208/ chicago/9780226028811.001.0001

Butler, J.E. (2001) Color-Line to Borderlands: the matrix of American ethnic studies. Seattle: University of Washington Press.

Cambium Learning (2012) Curriculum Audit - Mexican American Studies Department - Tucson Unified School District. http: / / www.acluaz.org/sites/ default / files/ documents / Ethnic\%20studies\%20audit\%20summary.pdf

Castel, R. (1991) From Dangerousness to Risk, in G. Burchell, C. Gordon \& P. Miller (Eds) The Foucault Effect: studies in governmentality, pp. 281-298. Hemel Hempstead: Harvester Press.

Center for Education Reform (2011) 2011-12 National Charter School and Enrollment Statistics. http: / / www.edreform.com/issues/ choice-charter-schools /

Dean, M. (2009) Governmentality: power and rule in modern society. Los Angeles: Sage.

Defert, D. (1991) 'Popular Life' and Insurance Technology, in G. Burchell, C. Gordon \& P. Miller (Eds) The Foucault Effect: studies in governmentality, pp. 211-233. Hemel Hempstead: Harvester Press.

Delpit, L. (1995) Other People's Children: cultural conflict in the classroom. New York: New Press.

Delpit, L. \& Dowdy, J.K. (Eds) (2004) The Skin That We Speak: thoughts on language and culture in the classroom. New York: New Press.

Diehn, D. (2007) Yes: key to nation's strength, Arizona Republic, 31 January, p. B8.

Donzelot, J. (2009) Michel Foucault's Understanding of Liberal Politics, in M.A. Peters (Ed.) Governmentality Studies in Education, pp. 17-33. Rotterdam: Sense.

Ellison, R. (1952) Invisible Man. New York: Modern Library.

English-Learner Law Survives (2008) Arizona Republic, 23 February, p. B1.

Equal Educational Opportunities Act of 1974 (1974) Public Law 93-380, 88 Stat. 514.

Ewald, F. (1991) Insurance and Risk, in G. Burchell, C. Gordon \& P. Miller (Eds) The Foucault Effect: studies in governmentality, pp. 197-210. Hemel Hempstead: Harvester Press.

Flores, M. (2006) At the Center of ELL Debate Is a Youngster Named Flores, Arizona Republic, 5 March. http:/ / www.azcentral.com/arizonarepublic/viewpoints/articles/0305flores0305.html

Gándara, P. \& Orfield, G. (2010) A Return to the 'Mexican Room’: the segregation of Arizona’s English learners, Civil Rights Project/Proyecto Derechos Civiles, University of California, Los Angeles. http: / / civilrightsproject.ucla.edu/research/k-12-education/language-minority-students

Gándara, P. \& Orfield, G. (2012) Segregating Arizona’s English Language Learners: a return to the 'Mexican room'? Teachers College Record, 114(9), 1-27.

Gándara, P. \& Rumberger, R. (2009) Immigration, Language, and Education: how does language policy structure opportunity? Teachers College Record, 111(3), 750-782.

Garcia, E.E., Lawton, K. \& Figueiredo, E.H.D. de (2012) The Education of English Language Learners in Arizona: a history of underachievement, Teachers College Record, 114(9), 1-18.

Gassen, S.G. (2009) Does Arizona’s System Serve? Arizona Daily Star, 19 April. www.azstarnet.com

Genesee, F., Lindholm-Leary, K., Saunders, W.M. \& Christian, D. (2006) Educating English Language Learners: a synthesis of research evidence. New York: Cambridge University Press. http: / / dx.doi.org/10.1017/CBO9780511499913

George, S. (1999) A Short History of Neoliberalism: twenty years of elite economics and emerging opportunities for structural change. Paper presented at conference on Economic Sovereignty in a Globalizing World, Bangkok, 24-26 March. http: / / www.globalexchange.org/resources/econ101/neoliberalismhist

Giroux, H.A. (2008) Against the Terror of Neoliberalism: politics beyond the age of greed. Boulder, CO: Paradigm.

Glass, G.V. (2008) Fertilizers, Pills, and Magnetic Strips: the fate of public education in America. Charlotte, NC: Information Age.

Gold, N. (2006) The High Schools English Learners Need. Policy Paper, University of California, Linguistic Minority Research Institute. http: / / escholarship.org/uc/item/6h72r068

Gordon, C. (1991) Governmental Rationality: an introduction, in G. Burchell, C. Gordon \& P. Miller (Eds) The Foucault Effect: studies in governmentality, pp. 1-51. Hemel Hempstead: Harvester Press. 
Harvey, D. (2005) A Brief History of Neoliberalism. Oxford: Oxford University Press.

Hayek, F.A. von (1944) The Road to Serfdom. Chicago: University of Chicago Press.

H.B. 2281, 49th Leg. Second Regular Session. (2010).

Horne v. Flores, Nos 08-289 and 08-294, 557 U.S. 129 S.Ct. 2579 (Decision announced June 25, 2009).

Intercultural Development Research Association (2012) US Supreme Court Ruling Horne vs. Flores. http://www.idra.org

Krikorian, T. (2006) Yuma Educators Support Governor's Vetoes, Knight Ridder Tribune Business News - The Sun, 27 January.

Lexington Institute (2009) Supreme Court’s Arizona Ruling Emphasizes Results. Press Release, 26 June. LexisNexis Academic database.

Lillie, K.E., Markos, A., Arias, M.B. \& Wiley, T.G. (2012) Separate and Not Equal: the implementation of Structured English Immersion in Arizona's classrooms, Teachers College Record, 114(9), 1-33.

Lopes, P. (2008) Guest Opinion: how House Dems see the 2008 session, Tucson Citizen, 16 January, p. 2 B. http:/ / www.tucsoncitizen.com/altss/printstory/opinion/ 74155

Martinez-Wenzl, M., Pérez, K.C. \& Gándara, P. (2012) Is Arizona’s Approach to Educating Its ELs Superior to Other Forms of Instruction? Teachers College Record, 114(9), 1-32.

Montini, E.J. (2009) Kids Still Losers in English-Learner Suit, Arizona Republic, 15 January. http: / / www.azcentral.com/arizonarepublic/local/ articles/2009/01/14/20090114Montini0115.html

Morrison Institute for Public Policy (2001) Five Shoes Waiting to Drop on Arizona's Future. Phoenix: Morrison Institute for Public Policy. http:/ / morrisoninstitute.asu.edu/

Morrison Institute for Public Policy (2012) Dropped? Latino Education and Arizona's Economic Future. Phoenix: Morrison Institute for Public Policy. http:/ / morrisoninstitute.asu.edu/

Napolitano, J. (2006) Gov. Napolitano Issues Statement on Judge’s Ruling on Flores, Fines. Press Release, 26 January. LexisNexis Academic database.

Oliff, P., Mai, C. \& Leachman, M. (2012) New School Year Brings More Cuts in State Funding for Schools, Center on Budget and Policy Priorities, 4 September. http: / / www.cbpp.org/cms/index.cfm?fa=view\&id=3825

Ordoñez, S. (2012) Students Protest Suspension of Ethnic Studies Program, New York Times Student Journalism Institute, 13 January. http:/ / nytimes-institute.com/

Peters, M. (2001) Education, Enterprise Culture and the Entrepreneurial Self: a Foucauldian perspective, Journal of Educational Enquiry, 2(2), 58-71.

Peters, M. (2005) The New Prudentialism in Education: actuarial rationality and the entrepreneurial self, Educational Theory, 55(2), 123-137. http:// dx.doi.org/10.1111/j.0013-2004.2005.00002.x

Peters, M., Maurer, S., Weber, S., Olssen, M. \& Besley, T. (Eds) (2008) Governmentality, Education and the Rise of Neoliberalism. Rotterdam: Sense.

Ramos, V.M. (2009) In Supreme Court Decision, Its Sink or Swim, Hispanosphere, 7 July. LexisNexis Academic Database.

Rios-Aguilar, C., Canche, M.S.G. \& Moll, L.C. (2012a) A Study of Arizona’s Teachers of English Language Learners, Teachers College Record, 114(9), 1-33.

Rios-Aguilar, C., Canche, M.S.G. \& Moll, L.C. (2012b) Implementing Structured English Immersion in Arizona: benefits, challenges, and opportunities, Teachers College Record, 114(9), 1-18.

Rios-Aguilar, C. \& Gándara, P. (2012) Horne v. Flores and the Future of Language Policy, Teachers College Record, 114(9), 1-13.

Rodriguez, R.C. (2012) Arizona’s ‘Banned’ Mexican American Books, Guardian, 18 January. http:/ / www.theguardian.com/us

Rowe, J.C. (Ed.) (2000) Post-Nationalist American Studies. Berkeley: University of California Press. http: / / dx.doi.org/10.1525/ california/9780520224384.001.0001

Scribner, K. (2005) Legislature's Foot-Dragging on Funding Education Threatens Students' Futures, Arizona Republic, 22 April, p. 6.

Scutari, C. \& Sherwood, R. (2006) English-Learner Plan Is Rejected. GOP Leaders: Napolitano’s idea costly, Arizona Republic, 1 February, p. B1.

Smitherman, G. (2004) Toward a National Public Policy on Language, in L. Delpit \& J.K. Dowdy (Eds) The Skin That We Speak: thoughts on language and culture in the classroom, pp. 163-178. New York: New Press. 
State of Arizona, House of Representatives (2010) House Bill 2281, Forty-Ninth Legislature, Second Regular Session. http: / / www.azleg.gov/legtext/49leg/2r/bills/hb2281p.pdf

Talton, J. (2006) At War with Education: the English-learner duel is just the latest in the legislature's vendetta, Arizona Republic, 29 January, p. V5.

Thatcher, M. (1987) Interview for Woman's Own ('No Such Thing as Society'), 23 September, Margaret Thatcher Foundation. http:/ / www.margaretthatcher.org/document/ 106689

Trasvina, J. (2006) Border Security and Immigration Issues, CQ Congressional Testimony, 26 July.

Uriarte, Richard de (2006) This Issue May Decide if Arizona Will Prosper, Arizona Republic, 5 March, p. V1.

US Census Bureau (2012) Arizona Quick Facts. http:/ / quickfacts.census.gov/ qfd/states/04000.html

US Department of Justice (2012) Types of Educational Opportunities Discrimination. http:/ / www.justice.gov/crt/about/edu/types.php

Wells, D. (2006) Legislature Betrays Students, Arizona Republic, 27 January, p. B8.

Wong-Fillmore, L. \& Snow, C. (2000) What Teachers Need to Know about Language, ERIC Clearinghouse on Languages and Linguistics. http:/ / people.ucsc.edu/ ktellez/wong-fill-snow.html

Zollers, N.J., Albert, L.R. \& Cochran-Smith, M. (2000) In Pursuit of Social Justice: collaborative research and practice in teacher education, Action in Teacher Education, 22(2), 1-14. http: / / dx.doi.org/ 10.1080/01626620.2000.10463000

MELINDA HOLLIS THOMAS ${ }^{\star}$ is a Doctoral Candidate of Curriculum and Instruction in the Mary Lou Fulton Teachers College, Arizona State University. She has served as a literature, composition, humanities, and multicultural education instructor in a variety of secondary and postsecondary contexts. Her primary research interests include curriculum policy and implementation, epistemologies of literacy, historical archives, and discursive rationalities of rule. She is a past Executive Editor of Current Issues in Education.Correspondence: mahollis@asu.edu

DINNY RISRI ALETHEIANI is a doctoral student in education with a concentration in curriculum studies at Mary Lou Fulton Teachers College, Arizona State University, USA. She is also currently a faculty at Council on Southeast Asia Studies at Yale University. She has taught courses on schooling and culture, multicultural education, alternative education and free schools, and linguistics. Her academic and research interests are in the area of curriculum studies, curriculum history, historical archives, free schools, alternative education, language learning and policy, education and history of education in Indonesia, and education in Southeast Asia.

DAVID LEE CARLSON is an Associate Professor in the Division of Teacher Education, Mary Lou Fulton Teachers College, Arizona State University, USA. He specializes in the methods of teaching English at the secondary level. Dr Carlson focuses primarily on the importance of critical and queer theory in education, specifically the works of Michel Foucault, Pierre Bourdieu, and Jacque Derrida. His most current work explores the pedagogies of friendship and how they interact with gender and sexuality studies in education. Dr Carlson wrote Composing a Care of the Self: a critical history of writing assessment in secondary English Education (Sense), and is currently working on two book projects. He was the 2012 recipient of the Promising Research Scholar award by Mary Lou Fulton Teachers College.

ANN DUTTON EWBANK is Clinical Associate Professor in the Mary Lou Fulton Teachers College, Arizona State University, USA. She served as a high school and middle school social studies teacher and librarian, and has taught undergraduate and graduate teacher education courses. Her primary interests are school library advocacy, information science, and instructional technology. She is a past president of the Arizona Library Association.

${ }^{\star}$ Contact author 